\title{
Polymeric Formulations of Liquid Inoculants with Rhizobia Exopolysaccharides Increase Survival and Symbiotic Efficiency of Bradyrhizobium Strains with Cowpea and Soybean
}

\author{
Thiago Palhares Farias \\ Universidade Federal de Lavras Departamento de Ciencia do Solo \\ Bruno Lima Soares \\ Universidade Federal de Lavras Departamento de Ciencia do Solo \\ Claudio Sérgio Barbosa D’Eça \\ Instituto Federal do Maranhao: Instituto Federal de Educacao Ciencia e Tecnologia do Maranhao \\ Fatima M S Moreira ( $\nabla$ fmoreira@ufla.br) \\ Universidade Federal de Lavras https://orcid.org/0000-0003-0159-5811
}

\section{Research Article}

Keywords: Elite strains, Vehicles, Cell protection, Shelf life, Glycine max, Vigna ungiculata.

Posted Date: June 28th, 2021

DOl: https://doi.org/10.21203/rs.3.rs-451580/v1

License: (c) (i) This work is licensed under a Creative Commons Attribution 4.0 International License. Read Full License 


\section{Abstract}

We studied the survival of four elite strains of Bradyrhizobium in liquid inoculants with three formulations with EPS extracted from other rhizobia genera, and their symbiotic efficiency, with soybean and cowpea, in a greenhouse. For this purpose, we verified the utility of formulations for maintaining the cell viability of strains by counting the colony forming units (CFU) per milliliter of the liquid inoculants with formulations over 90 days. Survival of the soybean inoculant strains, 29W and CPAC15, in the PEPS formulation had the largest number of CFU (>10 $\left.{ }^{10} \mathrm{~mL}^{-1}\right)$ after 90 days. For the cowpea inoculant strains, INPA3-1B and UFLA3-84, the formulations REPS ${ }_{1}$ had the largest number of CFU $\left(>10^{10} \mathrm{~mL}^{-1}\right)$ after 90 days. Symbiotic efficiency in soybean of the formulations PEPS and REPS 2 was higher than that shown by the commercial inoculant. For cowpea, the three formulations with EPS showed symbiotic efficiency bigger than that of the commercial inoculant.

\section{Introduction}

The production systems of the soybean [Glycine max (L.) Merr.] and cowpea [Vigna unguiculata (L.) Walp.] crops require large amounts of nitrogen. Biological nitrogen fixation (BNF) is a successful biotechnology responsible for a less expensive supply of $\mathrm{N}$ to these crops due to the use of inoculants with selected rhizobia strains.

Under laboratory conditions, a rhizobia strain may manifest considerable symbiotic efficiency, but to reproduce similar results under field conditions, the use of vehicles capable of effectively transporting a maximum of viable bacterial cells from industry to the field is necessary. Inoculants are formulations generally commercialized in powder, liquid, or granulated forms. However, most inoculants currently on the South-American market are liquid formulations. These formulations were developed to resolve problems associated with solid formulations (for example, the scarcity or limitation of natural peat deposits) or with their high cost of sterilization, as well as the difficulty of application with planting equipment (Stephens and Rask 2000; Tittabutr et al. 2007; Albareda et al. 2008).

Liquid inoculant formulations have big advantages, such as easy handling and management to obtain specific formulations, as well as greater shelf life and lower contamination. These advantages over peat formulations stimulate the development and application of liquid inoculant formulations, which has consolidated the market for this biotechnology (Sehrawat et al. 2017). Among the main characteristics that make for a good vehicle for liquid inoculants are low perishability, atoxicity, high water retention capacity, chemical and physical uniformity, and rapid release of rhizobia in the soil, as well as capacity for retaining sources of energy and nutrients able to support the survival and growth of the rhizobia (Sehrawat et al. 2017; Albareda et al. 2008). At the same time, these materials should be easy to obtain, abundant, and economically viable (Bashan et al. 2014). Liquid inoculants are microbial cultures or suspensions modified with chemical substances that are added to improve the rheological properties of aqueous systems, as well as to promote the formation of films that assist in adherence and physical protection of the bacterial cells. Among the main polymers of high molecular weight used in the formulation of liquid inoculants are sodium carboxymethylcellulose (CMC), polyvinylpyrrolidone (PVP), and sodium alginate (Sehrawat et al. 2017; Bashan et al. 2014).

Bacterial exopolysaccharides (EPS) are high molecular weight polymeric substances constituted by sugar monomers (Sutherland 2001; Donot et al. 2012) that are produced by several genera, including those belonging to $\mathrm{N}_{2}$-fixing Leguminosae nodulating genera, collectively known as rhizobia. The EPS form an external layer that surrounds the bacterial cells, thus favoring cell interactions, retention of extracellular enzymes, and sorption of 
particles and nutrients dissolved in the aqueous phase, allowing them to be used as energy and nutrient sources. These natural, atoxic, and biodegradable polymers not only perform these functions, but also play an essential role in protection of cells against desiccation, predation, and toxic effects of chemical agents and secondary metabolites, as well as in formation of biofilms (Flemming and Wingender 2010; Bomfeti et al. 2011; Kawaharada et al 2015; Cieśla et al. 2016). The EPS have wide industrial applications as emulsifiers, stabilizers, binders, coagulants, and suspending agents (Donot et al. 2012). They are also used as gelling agents to improve food quality and texture (Castellane et al. 2015). Therefore, rhizobia EPS may represent a viable vehicle in the formulation of liquid inoculants to substitute synthetic polymers.

In this study, we evaluated the survival of Bradyrhizobium elite strains in formulations with exopolysaccharides isolated from previously selected rhizobia strains as a vehicle. We also tested these formulations in the symbiosis of these elite strains with soybean and cowpea.

\section{Materials And Methods}

\section{Elite rhizobia strains and growing conditions}

The elite rhizobia strains used were: Bradyrhizobium elkanii - 29 W (= SEMIA 5019) and B. japonicum - CPAC 15 (= SEMIA 5079), efficient in symbiosis with soybean, selected after adaptation to Cerrado soils and released as inoculant strains in 1979 and 1992, respectively (Peres and Vidor 1980; Peres et al. 1993); as well as B. elkaniiINPA3-11B (= SEMIA 6463) and Bradyrhizobium viridifuturi symbiovar tropici - UFLA3-84 (= SEMIA 6461), efficient in symbiosis with cowpea, isolated from nodules of Centrosema sp. in Manaus and from pasture soils in the Amazon, respectively, using cowpea as a trap plant, and released as inoculant strains in 2004 (Lacerda et al. 2004). The strains were cultivated, until log phase $\left( \pm 10^{9} \mathrm{CFU} \mathrm{mL}^{-1}\right)$, in 79-medium (Fred and Waksman 1928), also called YMA (Vincent 1970) (10 g L-1 of mannitol, $0.01 \mathrm{~g} \mathrm{~L}^{-1}$ of $\mathrm{K}_{2} \mathrm{HPO}_{4}, 0.04 \mathrm{~g} \mathrm{~L}^{-1}$ of $\mathrm{KH}_{2} \mathrm{PO}_{4}, 0.05 \mathrm{~g} \mathrm{~L}^{-1}$ of $\mathrm{MgSO}_{4} .7 \mathrm{H}_{2} \mathrm{O}$, $0.01 \mathrm{~g} \mathrm{~L}^{-1}$ of $\mathrm{NaCl}, 0.4 \mathrm{~g} \mathrm{~L}^{-1}$ of powdered yeast extract, and $15 \mathrm{~g} \mathrm{~L}^{-1}$ of agar, with $\mathrm{pH}$ adjusted to $6.8-7.0$ ), at $28^{\circ} \mathrm{C}$.

\section{Exopolysaccharides used}

In this study, we used three exopolysaccharides: PEPS, extracted from Paraburkholderia sp. - UFLA 04-269, isolated from Macroptilium atropurpureum in rocky field soils (Araújo et al. 2017); REPS ${ }_{2}$, extracted from Rhizobium tropici - UFLA 05-16, isolated from Crotalaria spectabilis in gold mining soils (Rangel et al. 2017); and REPS 1 , extracted from Rhizobium tropici - CIAT 899 ${ }^{\top}$, isolated from acid soils of South America (Graham et al. 1994). In previous studies (data not published), these three EPS exhibited physicochemical characteristics that make them excellent vehicles for the formulation of liquid inoculants.

\section{EPS Extraction}

After growth at liquid 79-medium for six days, bacterial cells were removed from the culture medium by centrifugation at $10,000 \mathrm{~g}$ for 10 minutes at $4^{\circ} \mathrm{C}$, and cold $96 \%$ ethanol $\left(4^{\circ} \mathrm{C}\right)$ was added to the cell-free supernatant mixture at a ratio of 3:1 (v/v) (Castellane et al., 2014). At this stage, the formation of a supernatant gel and a precipitate was immediately observed. The mixture was cooled to $4^{\circ} \mathrm{C}$ for $24 \mathrm{~h}$. Ethanol was evaporated in a drying oven at $60^{\circ} \mathrm{C}$. The precipitation solvent enabled partial purification of the polymer by eliminating the soluble components of the culture medium (Castellane \& Lemos, 2007). 
The precipitated product was dried to a constant weight using a Labconco FreeZone 2.5 lyophilizer to verify the number of EPS obtained ( $\mathrm{g}$ of EPS per $\mathrm{L}$ of culture medium).

\section{Antibacterial trial of the three EPS}

We tested the possible antibacterial activity of the EPS to the elite inoculant strains 29 W, CPAC 15, INPA3-11B, and UFLA3-84 according to the procedures described by Bauer et al. (1966), with small modifications. In short, each strain was grown in solid 79-medium in a plate and exposed to a sterilized disk impregnated with $200 \mu \mathrm{L}$ of exopolysaccharide solution ( $10 \mathrm{mg} \mathrm{mL}^{-1}$ ) and to control treatments with sterile saline solution (disk imprenated with $\mathrm{NaCl} 0.85 \%, w / v)$ and two antibiotics (chloramphenicol and sulfazotrim). Antibiotics were made available in commercial disks at the concentration of $1 \mathrm{mg} \mathrm{mL}^{-1}$. These antibiotics were used as positive controls of antibacterial activities. Each strain was tested in triplicate. After incubation of the dishes at $28^{\circ} \mathrm{C}$ over a period of $144 \mathrm{~h}$, the inhibition zone diameter was measured.

\section{Preparation of liquid polymeric formulations of an exopolysaccharide base}

We used a modified 79-medium as a solution succinctly described as $40 \mathrm{~g} \mathrm{~L}^{-1}$ mannitol and $10 \mathrm{~g} \mathrm{~L}^{-1} \mathrm{glycerol}_{\text {as }}$ carbon sources, and $10 \mathrm{mg} \mathrm{L}^{-1} \mathrm{Fe}-\mathrm{EDTA}, 0.02 \mathrm{mg} \mathrm{L}^{-1} \mathrm{CuSO}_{4} \cdot 5 \mathrm{H}_{2} \mathrm{O}$, and $0.01 \mathrm{mg} \mathrm{L}^{-1} \mathrm{H}_{2} \mathrm{MoO}_{4} \cdot \mathrm{H}_{2} \mathrm{O}$ as metal ions. After performing tests with different EPS-concentrations ( $2 \%, 1 \%, 0.5 \%$, and $0.1 \%)$, we found the ideal concentration of each one of the EPS in the liquid formulations was $0.1 \%(\mathrm{w} / \mathrm{v})$. We prepared the formulations from each one of the exopolysaccharides, which constituted three formulations of liquid inoculants: formulation $1-$ REPS $_{1}$; formulation 2 - PEPS; formulation 3 - REPS 2 ; as well as a reference formulation with the original 79-medium (10 $\mathrm{g} \mathrm{L}^{-}$

1 mannitol) without the metal ions and the EPS. After preparation, the formulations were sterilized in an autoclave at $120^{\circ} \mathrm{C}$ at $1.0 \mathrm{~kg} \mathrm{~cm}^{2}$. Standardization of the concentration of the inocula was carried out as described above. Aliquots of $0.1 \mathrm{~mL}$ of the culture of the strains $29 \mathrm{~W}$, CPAC 15, INPA3-11B, and UFLA3-84 were inoculated in each one of the formulations. After that, the formulations were transferred to cone-bottom polypropylene centrifuge tubes, with a leak-proof elongated lid and $50 \mathrm{~mL}$ capacity, previously sterilized by gamma radiation. The samples were kept in an orbital shaker at $110 \mathrm{rpm}$ and $28^{\circ} \mathrm{C}$.

\section{Evaluation of hizobia growth and survival in the different liquid formulations}

The growth and survival of the Bradyrhizobium strains in each liquid formulation described above was evaluated at $5,10,20,30,60$, and 90 days of storage at ambient temperature $\left(28^{\circ} \mathrm{C}\right)$. The number of viable cells was determined by counting of colony forming units, using the serial decimal dilution method, in which a $1.0 \mathrm{~mL}$ aliquot of each formulation was successively diluted from $10^{-1}$ to $10^{-8}$ in saline solution $(0.85 \%, \mathrm{w} / \mathrm{v})$. After that, $20 \mu \mathrm{L}$ aliquots were inoculated on Petri dishes with 79-medium through the microdrop technique and then dried in a bacteriological chamber for 20 minutes before being inverted and then incubated at $28^{\circ} \mathrm{C}$ for 144 hours. Evaluations were made in quadruplicates. The number of colony forming units per milliliter was calculated using the the following formula:

Average CFU per milliliter $=$ average number of colonies for a dilution $\times$ dilution factor $\mathrm{x} 10$

\section{Evaluation of EPS enriched inoculants in symbiosis with cowpea and soybean in a greenhouse}

The studies were conducted in a greenhouse at the Instituto Federal do Maranhão, Campus São Luís - Maracanã, São Luís, MA, Brazil, from May to June 2017 to evaluate the performance of the liquid formulations of inoculants after one month of storage. The soil used, a Latossolo Amarelo Distrófico típico (Oxisol) (Santos 2018), was 
collected at a depth of 0 to $20 \mathrm{~cm}$. The soil was air dried, sieved in a four-millimeter mesh, homogenized, and placed in $8 \mathrm{~kg}$ pots. Soil samples were collected for chemical and textural characterization with the following results: $\mathrm{pH}$ of 4.8; organic matter of $1.97 \mathrm{dag} \mathrm{kg}^{-1} ; \mathrm{K}, \mathrm{P}$, and $\mathrm{S}$ of $21.36,2.78$, and $4.5 \mathrm{mg} \mathrm{dm}^{-3}$, respectively; $\mathrm{Ca}, \mathrm{Mg}, \mathrm{Al}, \mathrm{H}+\mathrm{Al}, \mathrm{SB}, \mathrm{t}$, and $T$ of $0.73,0.15,0.70,4.37,0.93,1.63$, and $5.30 \mathrm{cmol}_{\mathrm{C}} \mathrm{dm}^{-3}$, respectively; $\mathrm{V}$ and $\mathrm{m}$ of 17.64 and $42.94 \%$, respectively; $\mathrm{Zn}, \mathrm{Fe}, \mathrm{Mn}, \mathrm{Cu}$, and $\mathrm{B}$ of $1.00,232.74,1.61,0.19$, and $0.07 \mathrm{mg} \mathrm{dm}^{-3}$, respectively; and clay, silt, and sand fractions of 10,3 , and 87 dag ka $^{-1}$, respectively. Soil pH was determined in water at the soil:water proportion of 1:2.5; $\mathrm{H}+\mathrm{Al}$ was determined by the $\mathrm{Ca}(\mathrm{OAc})_{2}$ method in $0.5 \mathrm{~mol} \mathrm{~L}^{-1} ; \mathrm{pH}$ was 7.0 ; exchangeable $\mathrm{Ca}^{2+}, \mathrm{Mg}^{2+}$, and $\mathrm{Al}^{3+}$ were extracted with $1 \mathrm{~mol} \mathrm{~L}^{-1} \mathrm{KCl}$ and determined by titration; P and $\mathrm{K}$ were extracted by Mehlich-1 and analyzed by colorimetry $(\mathrm{P})$ and flame photometry $(\mathrm{K})$; organic carbon was determined by oxidation with potassium dichromate; and $\mathrm{Zn}, \mathrm{Mn}$, and $\mathrm{Cu}$ were extracted by Mehlich-1 and determined by atomic absorption spectrophotometry. The values of effective CEC ( $\mathrm{t}$ ), CEC at pH $7.0(\mathrm{t})$, sum of bases (SB), and the percentages of base saturation (V\%) and of aluminum saturation $(\mathrm{m})$ were indirectly obtained using the values of potential acidity, exchangeable bases, and exchangeable aluminum. Liming was performed to increase base saturation to $70 \%$, with application of $10.5 \mathrm{~g}$ per pot of dolomitic limestone (32\% of $\mathrm{CaCO}$ and $15 \%$ of $\mathrm{MgCO}$ - total neutralizing power (TNP) $=91 \%$ ) and subjected to 90 days of incubation. After that, basic fertilization was carried out as recommended by Malavolta (1980) with all the other nutrients, except for $\mathrm{N}$, through commercial compound sources. The application rates of macro- and micronutrients for each pot were $200 \mathrm{mg} \mathrm{P}, 150 \mathrm{mg} \mathrm{K}, 50 \mathrm{mg} \mathrm{S}, 5 \mathrm{mg} \mathrm{Zn,} 1.5 \mathrm{mg} \mathrm{Cu}, 3.6 \mathrm{mg} \mathrm{Mn}, 0.5 \mathrm{mg} \mathrm{B}$, and 0.1 $\mathrm{mg}$ Mo per $\mathrm{dm}^{3}$ of soil.

We used a completely randomized experimental design (CRD) with seven treatments, namely, three formulations of EPS, one commercial inoculant, one reference with original 79-medium without metal ions and without EPS, one control without mineral nitrogen $(-\mathrm{N})$, and one control with mineral nitrogen $(+\mathrm{N})\left(300 \mathrm{mg} \mathrm{dm}^{-3} \mathrm{de} \mathrm{N}\right.$, using urea as a fertilizer for all the formulations), with four replications. The symbiotic efficiency of the formulations was studied in soybean (29 W and CPAC 15) and cowpea (INPA3-11B and UFLA3-84) and compared with commercial inoculants for the two crops, namely, one liquid commercial formulation for soybean (SEMIA 5079 and SEMIA 5080, with 5.6 $\mathrm{x}$ $10^{9} \mathrm{CFU} \mathrm{mL}{ }^{-1}$ ) and one solid commercial formulation (peat inoculant) for cowpea (SEMIA 6461, with $1.0 \times 10^{9} \mathrm{CFU}$ $\left.\mathrm{g}^{-1}\right)$, as well as the reference inoculants for both the strains of soybean and cowpea, and the controls without and with mineral $\mathrm{N}$. The experimental plot consisted of one $8 \mathrm{~kg}$ pot containing two plants. The cultivars used were BRS 9180IPRO of soybean and BRS Guariba of cowpea. Seeds were inoculated in lots of 200 seeds with $200 \mu \mathrm{L}$ of liquid inoculant or $0.2 \mathrm{~g}$ of peat inoculant. The seeds inoculated with peat were pre-coated with $100 \mu \mathrm{L}$ of adhesive sucrose solution ( $10 \mathrm{~g}$ of sucrose in $100 \mathrm{~mL}$ of sterile $\mathrm{H}_{2} \mathrm{O}$ ).

The plants were grown in a mean temperature of $31.7^{\circ} \mathrm{C}$ and $67 \pm 8 \%$ relative humidity. They were harvested 45 days after planting for determination of the parameters of symbiotic efficiency (number of nodules - NN; nodule dry matter - NDM; shoot dry matter - SDM; relative efficiency - RE; shoot nitrogen concentration - SNC; and shoot nitrogen accumulation - SNA).

We also conducted a study in a greenhouse for the purpose of determining the density of the native populations of rhizobia (most probable number - MPN) in the soil of the previous experiment. Leonard pots were used with sterile sand and Hoagland and Arno (1950) solution and cowpea as a trap plant. At 30 days after germination, presence of nodules was recorded and bacterial quantification estimated in 1.4 × $10^{3}$ MPN, using the Cochran (1950) table.

\section{Statistical analysis}


The data were analyzed using the statistical analysis software Sisvar® (Ferreira, 2019). Before analysis of variance (ANOVA), the presupposed requirements of normality and homogeneity were checked. Firstly, when data evidenced lack of normality, they were transformed $(Y+0.5)^{0.5}$. The differences between the treatments were compared by the Scott Knott test $(p<0.01$ or $p<0.05)$.

\section{Results}

\section{Antibacterial trial of the three EPS}

The possible antibacterial activities of the PEPS, REPS1, and REPS2 against 29 W, CPAC 15, INPA3-11B, and UFLA384 were compared to chloramphenicol and sulfazotrim as positive controls with these same strains. The results show that the EPS do not exhibit antibacterial activity over the strains evaluated, i.e., no inhibition zone was detected. In contrast, the chloramphenicol exhibited antibacterial activities significantly $(p<0.05)$ greater than sulfazotrim in all the strains evaluated

\section{Evaluation of rhizobia growth and survival in the different liquid formulations}

As shown in Table 1, the PEPS formulation is the most important in maintaining survival of the strains $29 \mathrm{~W}$ and CPAC 15 soybean inoculants. The number of cells of $29 \mathrm{~W}$ and of CPAC 15 in the PEPS formulation is greater than that of the commercial inoculant and of the reference inoculant (Fig. 1). For cowpea, Table 2 shows that the formulations REPS ${ }_{1}$ and PEPS are most important in maintaining survival of the strain INPA3-11B. For UFLA3-84, the best formulation is REPS 1 . The number of cells of the two strains in the formulations is greater than that of the commercial inoculant and of the reference inoculant (Fig. 2).

The results show that there was no decline in cell viability of the strains studied either for soybean or for cowpea in the most significant formulations. At 90 days of storage, growth still remains in the logarithmic phase (Fig. 1 and 2). The three exopolysaccharides studied, PEPS extracted from Paraburkholderia sp. - UFLA 04-269, REPS 2 extracted from Rhizobium tropici - UFLA 05-16, and REPS ${ }_{1}$ extracted from $R$. tropici - CIAT $899^{\top}$, significantly contributed to the maintenance of cells viability.

\section{Study in a greenhouse}

At 45 days after germination, in the study of formulations with the strain $29 \mathrm{~W}$, soybean plants inoculated with the commercial inoculant exhibit the highest number of nodules and nodule dry matter (NN and NDM). For shoot dry matter and relative efficiency, the formulations PEPS, REPS 2 , and the commercial inoculant exhibit the second greatest mean value observed; the treatment with the highest mean value is the control with nitrogen. The PEPS formulation exhibits the highest shoot nitrogen concentration and accumulation (SNC and SNA) among the formulations, with values near the treatment with nitrogen (Table 3). For the study of formulations with the strain CPAC 15, the formulations BESP, REPS 2 , and the commercial inoculant exhibit a similar number of nodules $(p<$ 0.05). For the other variables of symbiotic efficiency, the two formulations with EPS exhibit mean values higher than the other formulations, but with a mean value lower than the control with nitrogen (Table 3). Relative efficiency of the formulations REPS 2 and PEPS is equal to or greater than $90 \%$ for the two elite strains for soybean.

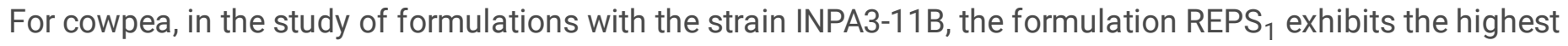
number of nodules and nodule dry matter (NN and NDM). For shoot dry matter (SDM) and shoot nitrogen concentration (SNC), the formulations with EPS and the commercial inoculant exhibit similar values $(p<0.05)$; 
nevertheless, the highest means observed are in the control with nitrogen. For shoot nitrogen accumulation (SNA), in the formulation with REPS 1 , the mean value observed is higher than the other formulations, and is below only the

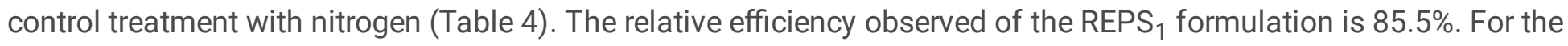
study of the formulations with the UFLA3-84 strain, the formulations PEPS and REPS ${ }_{2}$ exhibit the highest number of nodules and nodule dry matter (NN and NDM). For the other variables, these two formulations have values below only the control treatment with nitrogen (Table 4). The values observed for relative efficiency of the PEPS and REPS $_{2}$ formulations are 81.2 and $78.5 \%$, respectively.

\section{Discussion}

The EPS studied here can be used as carrier polymers in inoculant formulations, because they do not affect rhizobia survival. Studies show that exopolysaccharides can exhibit antibacterial activities, as shown by (Zhang et al. 2016) in EPS of the GST-6 strain studied in Escherichia coli, Shigella flexneri, S. typhimurium, and S.aureus. Another study shows that EPS that have sulfate groups have antibacterial activity in E. coli - ATCC 25922 and in Staphylococcus aureus - CMCC 26003 (Li and Shah 2014). The exopolysaccharides REPS1, PEPS, and REPS2 studied here do not have chemical groups described as antibacterial in a previous study (data not published), and the in vivo tests confirmed these results. Probably due to the affinity with rhizobia strains because they were extracted from other rhizobia genera and species.

The success of a new formulation mainly depends on the use of adequate vehicles (Bashan et al. 2014). In this study, three potential formulations for Bradyrhizobium in soybean and cowpea are evaluated using bacterial exopolysaccharides as carriers. According to our results, the PEPS formulation, in $B$. elkanii - $29 \mathrm{~W}$ and $B$. japonicum - CPAC 15, and REPS ${ }_{1}$ and PEPS formulations, in B. elkanii - INPA3-11B and B. sp. - UFLA3-84, show capacity for supporting cell viability the period of 90 days of storage. They are therefore potential formulations of liquid inoculants for soybean and cowpea. To our knowledge, this is the first exopolysaccharide isolated from rhizobia used in the development of a liquid inoculant formulation for soybean. Our results show that the use of this formulation can support a greater viability of Bradyrhizobium cells than the commercial formulation evaluated in this study (Table 1 and 2). Studies show that exopolysaccharides have physical and chemical properties capable of sorbing nutrients and carbon and energy sources, as well as of forming biofilms capable of protecting microbial cells (Sutherland 2001; Flemming and Wingender 2010; Castellane et al. 2015). They can also act as an additional source of nutrients and carbon to sustain bacterial growth during storage (Flemming and Wingender 2010; Lee et al. 2016). We previously discovered (data not published) that the EPS used in the formulations studied have chemical groups capable of reacting with metal ions, which allows retention of nutrients in their networks and later gradual release as the bacteria need these nutrients. As we observed, the number of rhizobia cells did not decrease over the period of 90 days of storage. This cell viability under prolonged conditions shows that there is no significant effect of accumulation of residues or microbial toxins, as other studies show (Lee et al. 2016). This observation suggests that the EPS in solution can alleviate stress during storage.

In some of our formulations, we observed better responses in relation to all the growth parameters in comparison to the treatment inoculated with commercial inoculant (Table 4). Other studies with CMC, PVP, and sodium alginate in polymeric formulations of inoculants show a significant increase in most of the growth parameters (Sehrawat et al. 2017). Better responses in plant growth parameters (number of nodules, nodule dry matter, shoot dry matter, relative efficiency, and shoot $\mathrm{N}$ concentration and accumulation) are more pronounced in the PEPS and REPS $_{2}$ formulations. The EPS of the two $R$. tropici strains behaved differently probably due to different genotypic 
differences. Although CIAT899 genome is already available, UFLA5-16 has only its 16SrRNA partially sequenced, however, genome sequencing is being planned to detect among others, possible genetic differences related to this feature.

We concluded that exopolysaccharides can be used in formulations of liquid inoculants as a vehicle that can support rhizobia cell growth, as well as provide protection and stability during storage in the period and N2efficiency in soil conditions. It is also amazing that EPS from different genera (Paraburkholderia and Rhizobium) have a positive effect on Bradyhizobium strains.

\section{Declarations}

Funding:We wish to thank the Programa de Bolsa de Incentivo à Qualificação dos Servidores do Instituto Federal de Educação, Ciência e Tecnologia do Maranhão (IFMA) for granting a doctoral scholarship to the first author; we are thankful for financial support from the Coordenação de Aperfeiçoamento de Pessoal de Nível Superior (CAPES), to the Conselho Nacional de Desenvolvimento Científico e Tecnológico (CNPq) for the research productivity scholarship and grant to the corresponding author, and to the Fundação de Amparo à Pesquisa de Minas Gerais (FAPEMIG) for financial support.

Conflicts of interest/Competing interests: The authors declare that they do not have conflicts of interest. This article does not involve studies with human or animal participants.

Availability of data and material (data transparency)

Authors' contributions (optional: please review the submission guidelines from the journal whether statements are mandatory) T.P. Farias, B.L. Soares, F,M.S. Moreira : Conceived of or designed study: Performed research, Analyzed data, Wrote the paper. D’Eça helped in performing research.

\section{References}

1. Albareda M, Rodríguez-Navarro DN, Camacho M, Temprano FJ (2008) Alternatives to peat as a carrier for rhizobia inoculants: Solid and liquid formulations. Soil Biol Biochem 40:2771-2779.

https://doi.org/10.1016/j.soilbio.2008.07.021

2. Araújo KS, Carvalho F de, Moreira FM de S (2017) Bukholderia strains promote Mimosa spp. growth but not Macroptilium atropurpureum. Rev Ciênc AGRONÔMICA 48:. https://doi.org/10.5935/1806-6690.20170005

3. Bashan Y, de-Bashan LE, Prabhu SR, Hernandez J-P (2014) Advances in plant growth-promoting bacterial inoculant technology: formulations and practical perspectives (1998-2013). Plant Soil 378:1-33. https://doi.org/10.1007/s11104-013-1956-x

4. Bauer AW, Kirby WM, Sherris JC, Turck M. (1996) Antibiotic susceptibility testing by a standardized single disk method. Am J Clin Pathol 45:493-496

5. Bomfeti CA, Florentino LA, Guimarães AP, et al (2011) Exopolysaccharides produced by the symbiotic nitrogenfixing bacteria of leguminosae. Rev Bras Ciênc Solo 35:657-671. https://doi.org/10.1590/S010006832011000300001

6. Castellane TCL, Macedo Lemos EG (2007) Composição de exopolissacarídeos produzidos por estirpes de rizóbios cultivados em diferentes fontes de carbono. Pesqui Agropecu Bras 42(10): 1503-1506. https://doi.org/10.1590/S0100-204X2007001000019 
7. Castellane TCL, Lemos MVF, Macedo Lemos EG (2014) Evaluation of the biotechnological potential of Rhizobium tropici strains for exopolysaccharide production. Carbohyd Polym 111: 191197. https://doi.org/10.1016/j.carbpol.2014.04.066

8. Castellane TCL, Persona MR, Campanharo JC, de Macedo Lemos EG (2015) Production of exopolysaccharide from rhizobia with potential biotechnological and bioremediation applications. Int J Biol Macromol 74:515522. https://doi.org/10.1016/j.ijbiomac.2015.01.007

9. Cieśla J, Kopycińska M, Łukowska M, et al (2016) Surface Properties of Wild-Type Rhizobium leguminosarum bv. trifolii Strain 24.2 and Its Derivatives with Different Extracellular Polysaccharide Content. PLOS ONE 11:e0165080. https://doi.org/10.1371/journal.pone.0165080

10. Cochran WG (1950) Estimation of Bacterial Densities by Means of the "Most Probable Number." Int Biom Soc 6:105-116

11. Donot F, Fontana A, Baccou JC, Schorr-Galindo S (2012) Microbial exopolysaccharides: Main examples of synthesis, excretion, genetics and extraction. Carbohydr Polym 87:951-962. https://doi.org/10.1016/j.carbpol.2011.08.083

12. Ferreira DF (2019) Sisvar: a computer analysis system to fixed effects split plot type designs. Rev Bras Biom 37:529. https://doi.org/10.28951/rbb.v37i4.450

13. Flemming H-C, Wingender J (2010) The biofilm matrix. Nat Rev Microbiol 8:623-633. https://doi.org/10.1038/nrmicro2415

14. Fred E, Waksman S (1928) Laboratory manual of general microbiology with special reference to the microorganisms of the soil. McGraw-Hill Book N Y

15. Graham PH, Draeger KJ, Ferrey ML, et al (1994) Acid pH tolerance in strains of Rhizobium and Bradyrhizobium, and initial studies on the basis for acid tolerance of Rhizobium tropici UMR1899. Can J Microbiol 40:198-207. https://doi.org/10.1139/m94-033

16. Hoagland DR, Arnon DI (1950) The water-culture method for growing plants without soil. Calif Agric Exp Stn 347:32

17. Kawaharada Y, Kelly S, Nielsen MW, et al (2015) Receptor-mediated exopolysaccharide perception controls bacterial infection. Nature 523:308-312. https://doi.org/10.1038/nature14611

18. Lacerda AM, Moreira FMDS, Andrade MJB, Soares ALDL (2004) Efeito de estirpes de rizóbio sobre a nodulação e produtividade do feijão-caupi. Rev Ceres 51:67-82

19. Lee S-K, Lur H-S, Lo K-J, et al (2016) Evaluation of the effects of different liquid inoculant formulations on the survival and plant-growth-promoting efficiency of Rhodopseudomonas palustris strain PS3. Appl Microbiol Biotechnol 100:7977-7987. https://doi.org/10.1007/s00253-016-7582-9

20. Li S, Shah NP (2014) Antioxidant and antibacterial activities of sulphated polysaccharides from Pleurotus eryngii and Streptococcus thermophilus ASCC 1275. Food Chem 165:262-270.

https://doi.org/10.1016/j.foodchem.2014.05.110

21. Malavolta E (1980) Elementos de nutrição mineral de plantas, 1st edn. Agronômica Ceres

22. Peres JRR, Mendes I, Suhet A, Vargas MAT (1993) Eficiência e competitividade de estirpes de rizóbio para soja em solos de cerrado. Rev Bras Ciênc Solo 17:357-363

23. Peres JRR, Vidor C (1980) Seleção de estirpes de Rhizobium japonicum e competitividade por sítios de infecção nodular em cultivares de soja (Glycine max (L.) MERRIL). Agron Sulriograndene 16:205-219 
24. Rangel W de M, de Oliveira Longatti SM, Ferreira PAA, et al (2017) Leguminosae native nodulating bacteria from a gold mine As-contaminated soil: Multi-resistance to trace elements, and possible role in plant growth and mineral nutrition. Int J Phytoremediation 19:925-936. https://doi.org/10.1080/15226514.2017.1303812

25. Santos HG dos (2018) Sistema brasileiro de classificação de solos, 5ạ edição revista e ampliada. Embrapa, Brasília, DF

26. Sehrawat A, Yadav A, Anand RC, et al (2017) Enhancement of shelf life of liquid biofertilizer containing Rhizobium sp. infecting mungbean (Vigna radiata L.). LEGUME Res - Int J. https://doi.org/10.18805/Ir.v0i0.7648

27. Stephens JHG, Rask HM (2000) Inoculant production and formulation. Field Crops Res 65:249-258. https://doi.org/10.1016/S0378-4290(99)00090-8

28. Sutherland IW (2001) Microbial polysaccharides from Gram-negative bacteria. Int Dairy J 11:663-674. https://doi.org/10.1016/S0958-6946(01)00112-1

29. Tittabutr P, Payakapong W, Teaumroong N, et al (2007) Growth, Survival and Field Performance of Bradyrhizobial Liquid Inoculant Formulations with Polymeric Additives. ScienceAsia 33:069. https://doi.org/10.2306/scienceasia1513-1874.2007.33.069

30. Vincent JM (1970) A Manual for the Practical Study of Root-nodule Bacteria, 15th edn. International Biological Programme [by] Blackwell Scientific

31. Zhang J, Cao Y, Wang J, et al (2016) Physicochemical characteristics and bioactivities of the exopolysaccharide and its sulphated polymer from Streptococcus thermophilus GST-6. Carbohydr Polym 146:368-375. https://doi.org/10.1016/j.carbpol.2016.03.063

\section{Tables}

Table 1. Growth of Bradyrhizobium elkanii - 29 W and Bradyrhizobium japonicum - CPAC 15 according to different formulations, which were stored for 90 days.

\begin{tabular}{|c|c|c|c|}
\hline \multicolumn{2}{|c|}{ Bradyrhizobium elkanii - 29 W } & \multicolumn{2}{|c|}{ Bradyrhizobium japonicum - CPAC 15} \\
\hline Formulation & Log CFU mL $\mathrm{mL}^{-1}$ & Formulation & Log CFU mL $\mathrm{mL}^{-1}$ \\
\hline $\mathrm{REPS}_{1}$ & $9.76 \pm 0.01 \mathrm{e}$ & REPS $_{1}$ & $10.07 \pm 0.01 c$ \\
\hline PEPS & $10.09 \pm 0.01 a$ & PEPS & $10.14 \pm 0.00 a$ \\
\hline $\mathrm{REPS}_{2}$ & $10.04 \pm 0.01 b$ & REPS $_{2}$ & $10.12 \pm 0.59 b$ \\
\hline Reference & $9.93 \pm 0.01 d$ & Reference & $9.35 \pm 0.02 e$ \\
\hline Commercial Inoculant & $9.98 \pm 0.01 c$ & Commercial Inoculant & $9.98 \pm 0.01 d$ \\
\hline CV (\%) & 2.67 & CV (\%) & 2.34 \\
\hline
\end{tabular}

The results of the $t$ test for variance among the means ( \pm standard error) from observations of the study of the growth of inoculant strains in different formulations showed significant $(p<0.01)$ differences. Among lines, the values with different letters are significantly different.

Table 2. Growth of Bradyrhizobium elkanii - INPA3-11B and Bradyrhizobium sp. - UFLA3-84 according to different formulations, which were stored for 90 days. 


\begin{tabular}{llll}
\multicolumn{2}{l}{$\begin{array}{l}\text { Bradyrhizobium elkanii - INPA3-11B } \\
\text { Formulation }\end{array}$} & \multicolumn{2}{l}{ Bradyrhizobium sp. - UFLA3-84 } \\
REPS1 & $10.07 \pm 0.01 \mathrm{a}$ & REPS1 & Log CFU mL ${ }^{-1}$ \\
PEPS & $10.07 \pm 0.03 \mathrm{a}$ & PEPS & $10.16 \pm 0.01 \mathrm{a}$ \\
REPS2 & $9.79 \pm 0.04 \mathrm{~b}$ & REPS 2 & $9.87 \pm 0.01 \mathrm{c}$ \\
Reference & $9.56 \pm 0.02 \mathrm{c}$ & Reference & $9.97 \pm 0.02 \mathrm{~b}$ \\
Commercial Inoc. & $9.54 \pm 0.01 \mathrm{c}$ & Commercial Inoc. & $9.54 \pm 0.01 \mathrm{e}$ \\
CV $(\%)$ & 7.78 & CV $(\%)$ & 3.79
\end{tabular}

The results of the $t$ test for variance among the means ( \pm standard error) from observations of the study of growth of inoculant strains in different formulations showed significant $(p<0.01)$ differences. Among lines, the values with different letters are significantly different.

Table 3. Mean values of number of nodules (NN), nodule dry matter (NDM), shoot dry matter (SDM), relative efficiency (RE), shoot nitrogen concentration and accumulation (SNC and SNA) for the soybean cultivar BRS 9180IPRO. 


\begin{tabular}{|c|c|c|c|c|c|c|}
\hline \multirow[t]{2}{*}{ Formulation } & NN & NDM & SDM & RE & SNC & SNA \\
\hline & Unit & mg plant $^{-1}$ & g plant $^{-1}$ & ........................ & & g plant $^{-1}$ \\
\hline \multicolumn{7}{|c|}{ Bradyrhizobium elkanii - $29 \mathrm{~W}$} \\
\hline REPS $_{1}$ & $82.50 \pm 1.85 \mathrm{c}$ & $265.06 \pm 3.92 d$ & $9.76 \pm 0.13 c$ & $68.93 \pm 0.63 c$ & $3.30 \pm 0.18 d$ & $32.24 \pm 1.88 \mathrm{~d}$ \\
\hline PEPS & $108.50 \pm 1.32 b$ & $371.65 \pm 8.90 b$ & $12.81 \pm 0.14 b$ & $90.49 \pm 1.31 b$ & $4.90 \pm 0.12 b$ & $62.76 \pm 1.33 b$ \\
\hline REPS $_{2}$ & $104.00 \pm 2.74 b$ & $340.55 \pm 9.65 \mathrm{c}$ & $12.70 \pm 0.06 \mathrm{~b}$ & $89.69 \pm 0.93 b$ & $4.20 \pm 0.12 c$ & $53.34 \pm 1.49 c$ \\
\hline Reference & $49.75 \pm 1.25 d$ & $146.63 \pm 13.00 \mathrm{e}$ & $5.16 \pm 0.09 d$ & $36.47 \pm 0.81 d$ & $3.60 \pm 0.09 d$ & $18.61 \pm 0.74 \mathrm{e}$ \\
\hline Inoculant & $121.00 \pm 1.68 \mathrm{a}$ & $400.27 \pm 11.34 a$ & $13.03 \pm 0.05 b$ & $91.98 \pm 0.71 b$ & $4.10 \pm 0.06 c$ & $53.40 \pm 0.78 c$ \\
\hline Control $-\mathrm{N}$ & $11.25 \pm 1.65 \mathrm{e}$ & $36.77 \pm 5.54 f$ & $4.79 \pm 0.07 e$ & $33.81 \pm 0.55 \mathrm{e}$ & $2.78 \pm 0.19 \mathrm{e}$ & $13.30 \pm 0.99 f$ \\
\hline Control $+\mathrm{N}$ & $0.00 \pm 0.00 f$ & $0.00 \pm 0.00 \mathrm{~g}$ & $14.16 \pm 0.11 a$ & $100.00 \pm 0.00 a$ & $5.38 \pm 0.19 a$ & $76.14 \pm 2.90 \mathrm{a}$ \\
\hline CV (\%) & 4.94 & 7.70 & 1.89 & 2.18 & 7.12 & 7.26 \\
\hline
\end{tabular}

Bradyrhizobium japonicum - CPAC 15

\begin{tabular}{lllllll}
\hline REPS $_{1}$ & $97.00 \pm 5.59 \mathrm{~b}$ & $317.51 \pm 21.28 \mathrm{~b}$ & $12.63 \pm 0.52 \mathrm{~b}$ & $89.11 \pm 3.27 \mathrm{~b}$ & $3.75 \pm 0.09 \mathrm{c}$ & $47.46 \pm 3.00 \mathrm{~d}$ \\
\hline PEPS & $119.50 \pm 1.71 \mathrm{a}$ & $395.91 \pm 5.56 \mathrm{a}$ & $14.19 \pm 0.05 \mathrm{a}$ & $100.19 \pm 0.51 \mathrm{a}$ & $4.38 \pm 0.18 \mathrm{~b}$ & $62.06 \pm 2.38 \mathrm{~b}$ \\
\hline REPS $_{2}$ & $115.25 \pm 3.33 \mathrm{a}$ & $381.98 \pm 12.21 \mathrm{a}$ & $13.78 \pm 0.28 \mathrm{a}$ & $97.26 \pm 1.67 \mathrm{a}$ & $4.05 \pm 0.03 \mathrm{~b}$ & $55.80 \pm 1.30 \mathrm{c}$ \\
\hline Reference & $49.75 \pm 1.25 \mathrm{c}$ & $146.63 \pm 13.00 \mathrm{c}$ & $5.16 \pm 0.09 \mathrm{c}$ & $36.47 \pm 0.81 \mathrm{c}$ & $3.60 \pm 0.09 \mathrm{c}$ & $18.61 \pm 0.74 \mathrm{e}$ \\
\hline Inoculant & $121.00 \pm 1.68 \mathrm{a}$ & $400.27 \pm 11.34 \mathrm{a}$ & $13.03 \pm 0.05 \mathrm{~b}$ & $91.98 \pm 0.71 \mathrm{~b}$ & $4.10 \pm 0.06 \mathrm{~b}$ & $53.40 \pm 0.78 \mathrm{c}$ \\
\hline Control $-\mathrm{N}$ & $11.25 \pm 1.65 \mathrm{~d}$ & $36.77 \pm 5.54 \mathrm{~d}$ & $4.79 \pm 0.07 \mathrm{c}$ & $33.81 \pm 0.55 \mathrm{c}$ & $2.76 \pm 0.19 \mathrm{~d}$ & $13.30 \pm 0.99 \mathrm{e}$ \\
\hline Control $+\mathrm{N}$ & $0.00 \pm 0.00 \mathrm{e}$ & $0.00 \pm 0.00 \mathrm{e}$ & $14.16 \pm 0.11 \mathrm{a}$ & $100.00 \pm 0.00 \mathrm{a}$ & $5.38 \pm 0.19 \mathrm{a}$ & $76.14 \pm 2.90 \mathrm{a}$ \\
\hline CV $(\%)$ & 7.77 & 9.75 & 4.18 & 3.76 & 6.64 & 8.40
\end{tabular}

Mean values followed by the same letters belong to the same group according to the Scott-Knott test at the $5 \%$ level of probability.

Table 4. Mean values of the number of nodules (NN), nodule dry matter (NDM), shoot dry matter (SDM), relative efficiency (RE), shoot nitrogen concentration and accumulation (SNC and SNA) for the cowpea cultivar BRS Guariba. 


\begin{tabular}{|c|c|c|c|c|c|c|}
\hline \multirow[t]{2}{*}{ Formulation } & NN & NDM & SDM & RE & SNC & SNA \\
\hline & Unit & mg plant $^{-1}$ & g plant $^{-1}$ & $\ldots \ldots \ldots . . \% \ldots \ldots \ldots \ldots$ & & g plant $^{-1}$ \\
\hline \multicolumn{7}{|c|}{ Bradyrhizobium elkanii - INPA3-11B } \\
\hline REPS $_{1}$ & $60.00 \pm 3.94 a$ & $228.32 \pm 11.35 a$ & $11.99 \pm 0.20 b$ & $85.48 \pm 1.53 b$ & $4.23 \pm 0.14 b$ & $50.63 \pm 1.76 b$ \\
\hline PEPS & $49.50 \pm 3.80 \mathrm{~b}$ & $186.53 \pm 12.95 b$ & $10.89 \pm 0.27 \mathrm{~b}$ & $77.64 \pm 2.00 \mathrm{c}$ & $4.15 \pm 0.12 b$ & $45.17 \pm 1.57 \mathrm{c}$ \\
\hline REPS $_{2}$ & $51.25 \pm 2.10 \mathrm{~b}$ & $194.90 \pm 15.42 b$ & $10.63 \pm 0.43 b$ & $75.75 \pm 2.93 c$ & $4.13 \pm 0.06 \mathrm{~b}$ & $43.90 \pm 2.46 c$ \\
\hline Reference & $30.75 \pm 2.10 \mathrm{c}$ & $121.06 \pm 8.98 \mathrm{c}$ & $7.78 \pm 0.14 \mathrm{c}$ & $55.44 \pm 1.05 d$ & $3.80 \pm 0.11 b$ & $29.58 \pm 1.24 d$ \\
\hline Inoculant & $51.00 \pm 1.68 \mathrm{~b}$ & $202.17 \pm 2.84 b$ & $10.42 \pm 0.34 b$ & $74.31 \pm 2.51 c$ & $4.03 \pm 0.02 b$ & $41.95 \pm 1.47 \mathrm{c}$ \\
\hline Control $-\mathrm{N}$ & $24.00 \pm 2.12 \mathrm{c}$ & $88.63 \pm 9.54 d$ & $6.66 \pm 0.18 d$ & $47.47 \pm 1.33 e$ & $3.25 \pm 01.7 \mathrm{c}$ & $21.63 \pm 1.21 \mathrm{e}$ \\
\hline Control +N & $0.00 \pm 0.00 \mathrm{~d}$ & $0.00 \pm 0.00 \mathrm{e}$ & $14.03 \pm 0.02 a$ & $100.00 \pm 0.00 a$ & $5.38 \pm 0.11 a$ & $75.38 \pm 1.45 a$ \\
\hline CV (\%) & 13.47 & 13.84 & 4.99 & 5.03 & 5.51 & 7.45 \\
\hline
\end{tabular}

\section{Bradyrhizobium sp. - UFLA3-84}

\begin{tabular}{|c|c|c|c|c|c|c|}
\hline REPS $_{1}$ & $46.50 \pm 4.73 b$ & $210.20 \pm 17.86 b$ & $10.06 \pm 0.48 c$ & $70.58 \pm 3.04 \mathrm{c}$ & $4.10 \pm 0.17 b$ & $41.41 \pm 3.27 \mathrm{~b}$ \\
\hline PEPS & $59.75 \pm 3.22 a$ & $271.30 \pm 19.51 a$ & $11.58 \pm 0.48 b$ & $81.18 \pm 2.87 b$ & $4.15 \pm 0.18 b$ & $48.03 \pm 2.90 \mathrm{~b}$ \\
\hline REPS $_{2}$ & $54.00 \pm 2.86 a$ & $243.15 \pm 13.94 a$ & $11.18 \pm 0.11 b$ & $78.45 \pm 1.02 b$ & $4.25 \pm 0.30 \mathrm{~b}$ & $47.55 \pm 3.60 \mathrm{~b}$ \\
\hline Reference & $30.75 \pm 2.10 c$ & $121.06 \pm$ & $7.78 \pm 0.14 d$ & 55.44 & $3.80 \pm 0.11 \mathrm{c}$ & 29.5 \\
\hline Inoculant & $51.00 \pm 1.68 \mathrm{~b}$ & $202.17 \pm 2.84 \mathrm{~b}$ & $10.42 \pm 0.34 \mathrm{c}$ & $74.31 \pm 2.51 \mathrm{c}$ & $4.03 \pm 0.02 b$ & $41.95 \pm 1.47 \mathrm{~b}$ \\
\hline Control $-\mathrm{N}$ & $24.00 \pm 2.12 \mathrm{c}$ & $88.63 \pm 9.54 d$ & $6.66 \pm 0.18 d$ & $47.47 \pm 1.33 d$ & $3.25 \pm 01.7 \mathrm{c}$ & $21.63 \pm 1.21 \mathrm{c}$ \\
\hline Control $+\mathrm{N}$ & $0.00 \pm 0.00 \mathrm{~d}$ & $0.00 \pm 0.00 \mathrm{e}$ & $14.03 \pm 0.02 a$ & $100.00 \pm 0.00 a$ & $5.38 \pm 0.11 a$ & $75.38 \pm 1.45 a$ \\
\hline $\mathrm{CV}(\%)$ & 14.61 & 14.86 & 6.02 & 5.69 & 8.44 & 11.12 \\
\hline
\end{tabular}

Mean values followed by the same letters belong to the same group according to the Scott-Knott test at the $5 \%$ level of probability.

\section{Figures}



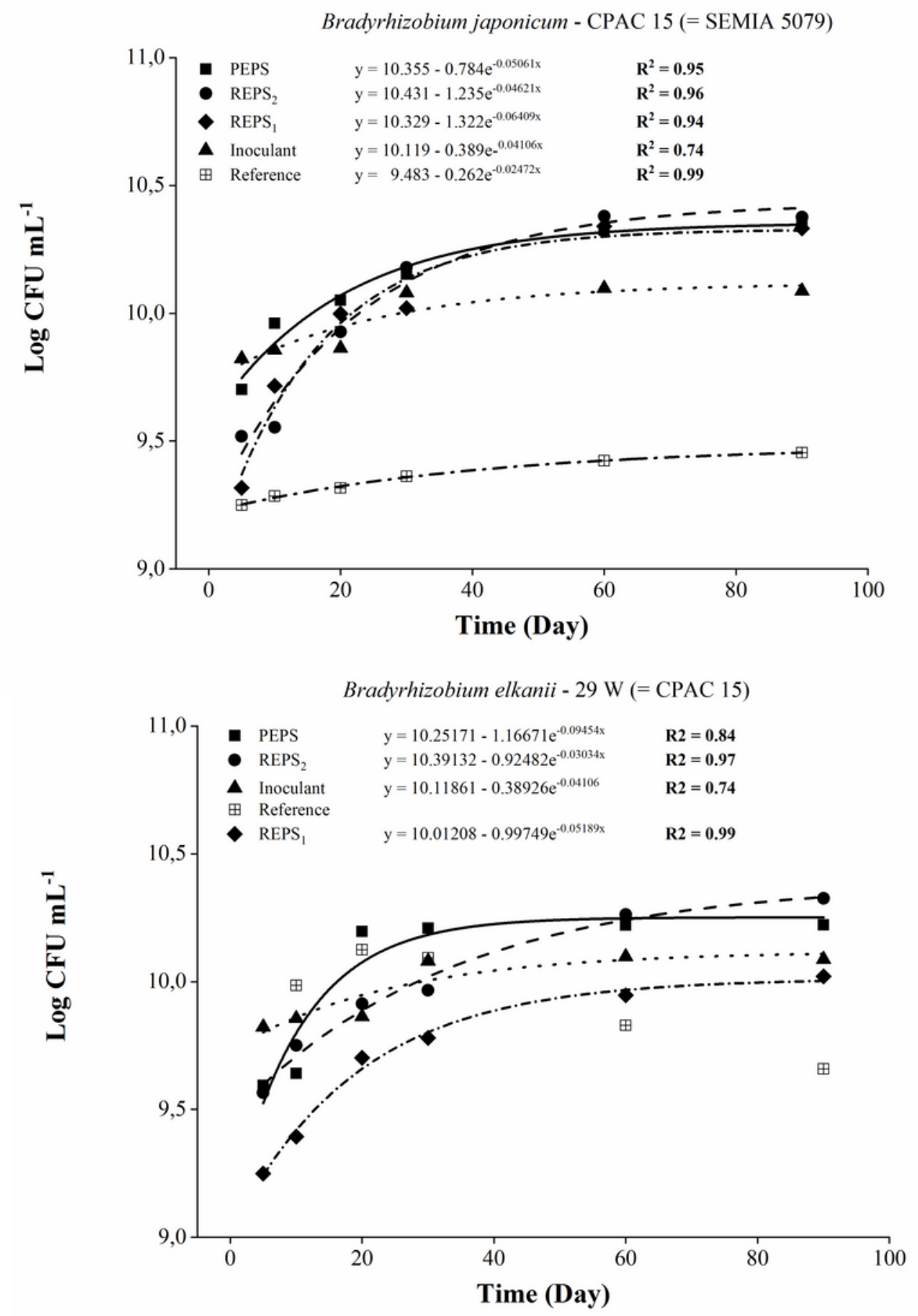

Figure 1

The number of cells of $29 \mathrm{~W}$ and of CPAC 15 in the PEPS formulation is greater than that of the commercial inoculant and of the reference inoculant (Fig. 1). 

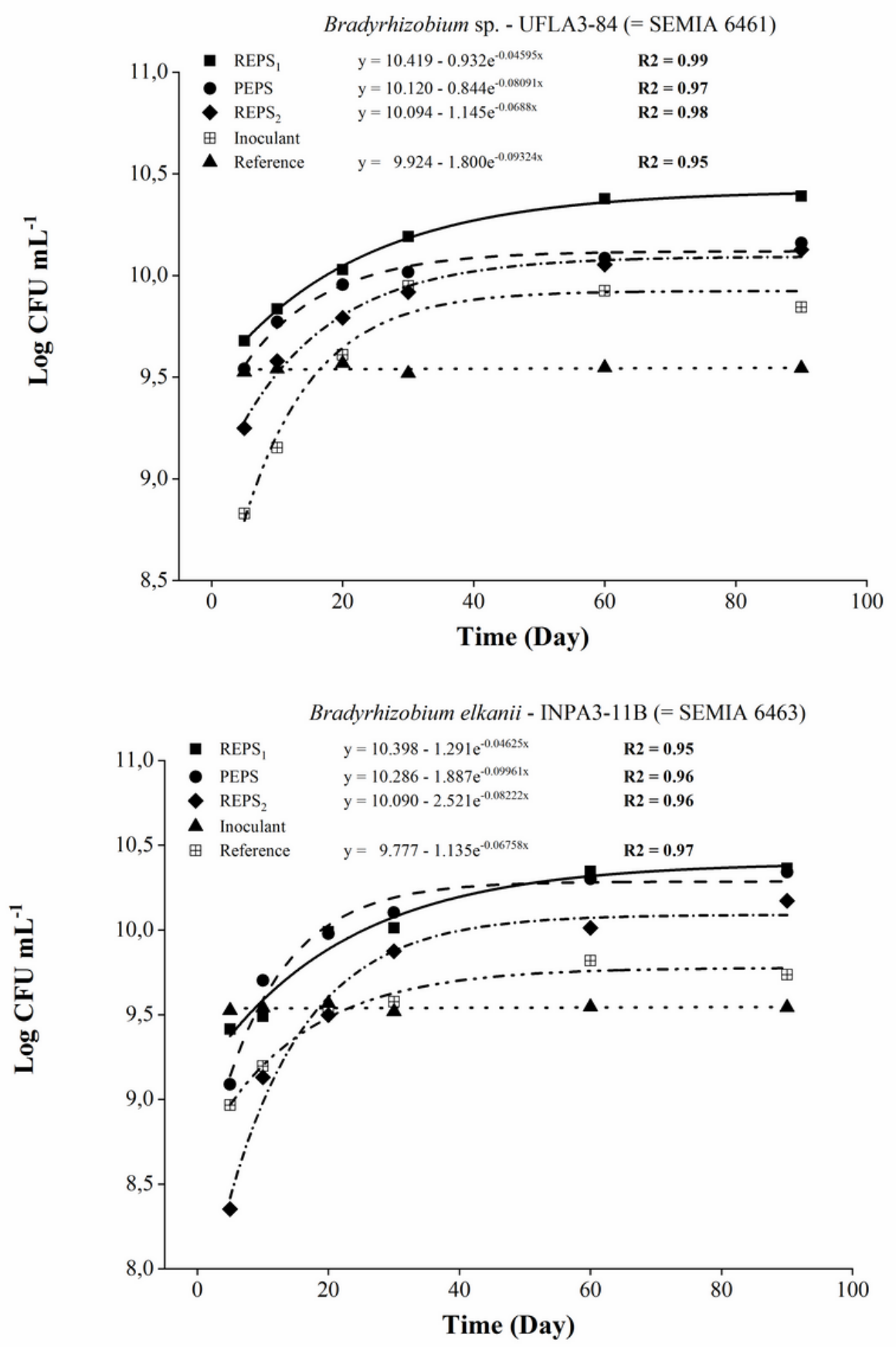

Figure 2

The number of cells of the two strains in the formulations is greater than that of the commercial inoculant and of the reference inoculant (Fig. 2). 